\title{
小児口蓋扁桃摘出症例の検討
}

\author{
唐木 りえ・藤原 聖子*
}

\section{A Review of 77 Cases, Tonsillectomy in Children}

\author{
Rie Karaki \\ (Kagawa Children's Hospital) \\ Seiko Fujiwara \\ (Kagawa Medical University)
}

\begin{abstract}
Results of tonsillectomy in 77 patients consisting mainly of children from October 1998 to September 2001 are reported. The patients were divided into four illness groups: 40 patients with tonsil hypertrophy, 30 with recurrent tonsillitis, 5 with chronic tonsillitis, and 2 with focal tonsillitis. The ages ranged from 1 to 21 years. Sixty percent of the patients were under 6 years of age. Chief complaints were recurrent tonsillitis, snoring and sleep apnea.

A questionnaire survey was performed to investigate the postoperative effects of tonsillectomy on subjective symptoms for 77 patients. Improvement of preoperative subjective symptoms was found in 41 of 42 patients $(97.6 \%)$. Almost all patients were satisfied with having undergone tonsillectomy.
\end{abstract}

Key words : tonsillectomy, tonsillar diseases, questionnaire survey study

\section{はじめに}

口蓋扁桃摘出術（以下，扁摘）は耳鼻咽喉科医にとっ て一般的に行われる手術であり，その検討も多くの施設 において報告されている。しかし，疾患の性質上，日常 臨床において術後の状態について知る機会は少ない。

今回，われわれは香川小児病院耳鼻咽喉科にて扁摘を 行った症例につき，患者背景の検討を行らとともに術後 状態についてアンケート調查を行ったので, 若干の文献 的考察とともに報告する.

\section{方法}

対象は当科において 1998 年 10 月から 2001 年 9 月まで の 3 年間に扁摘を行った 77 例（男児 52 例，女児 25 例） である，疾患は扁桃肥大群，習慣性扁桃炎群，その他の 扁摘群の 3 群に分類した。 扁桃肥大により睡眠中の無呼
吸や摂食障害, 胸郭変形を認めるため手術を行ったもの を扁桃肥大群, 年 4 回以上の急性増悪を反復したものを 習慣性扁桃炎群, 3 回以下の扁桃炎や扁桃が病巣と思わ れた腎疾患のために扁摘をした症例をその他の扁摘群と した. 当院の手術の適応基準としては上記にも示したが, 肥大により機能障害をきたしている症例, 年 4 回以上の 急性増悪を反復する症例, 扁桃が病巣と考えられる症例, 年 3 回以下でも増悪時の症状がひどく, 学校を長く休ん だり家族が手術を希望したりする場合である，扁桃肥大 群 40 例, 習慣性扁桃炎群 30 例, その他の扁摘群 7 例で あった (図 1).そのうちアデノイド増殖症を合併してい たのは 55 例であった。これらの対象において（1）疾患 別症例数，（2）年齢・性別，(3) 手術患者数の推移，(4) 初診時主訴，(5）ASO，（6）術式，(7) 術後の状態の項 目について検討した。術後の状態については 77 例全例に 


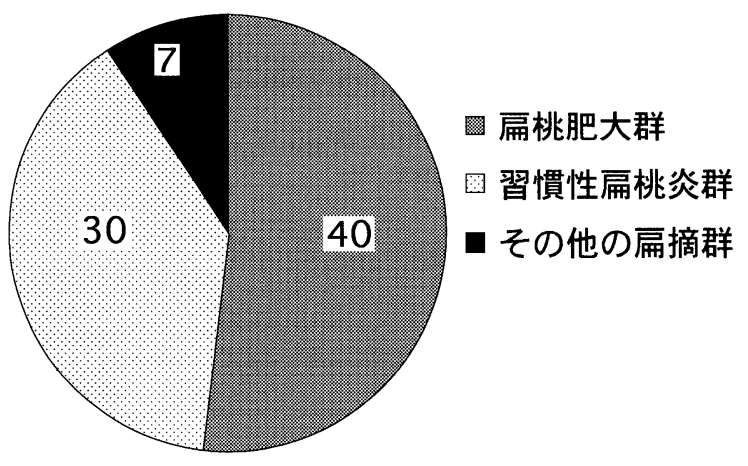

図 1 疾患別症例数

アンケート用紙を郵送し，調查を行った．アンケートの 時期は 2001 年 9 月末から 10 月末までの 1 月月間で行っ た. 内容としては 1）現在の年齢・手術時の年齢，2）手 術を受ける原因となった症状，3）手術時の他疾患への罹 患の有無，4）術後の症状の改善度，5）手術に対する满 足度を質問した。

\section{結 果}

（1）年齢・性別

男児 52 例, 女児 25 例の計 77 例で性差は約 $2: 1$ で男 性が多かった. 年齢は 1 歳 6 カ月〜 14 歳で平均 5.7 歳で あった. 年齢別では $4 \sim 6$ 歳までが 47 例と多く, 全体の 約 6 割を占めていた（図 2). 疾患別に年齢分布をみると 扁桃肥大群では $4 \sim 6$ 歳を中心に低年齢層に, 炎症のみ られた習慣性扁桃炎群, その他の扁摘群は扁桃肥大群に 比べやや高年齢層にみられた（図 3 ).

(2) 手術患者数の推移

3 年間を 1 年ごとに区切ってそれぞれの群について患
(例)

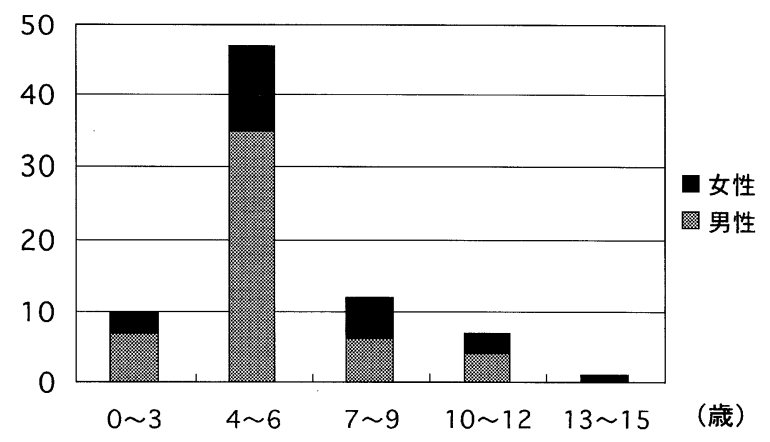

図 2 年齢・性別

者数の推移をみてみた. 最初の 1 年は習慣性扁桃炎群の 割合が多いが, 2 年目, 3 年目は扁桃肥大群の割合が高 かった．また，アデノイドを合併切除している症例をみ てみると, 全体では徐々に増加していた（図 4). 疾患別 では扁桃肥大群が 40 例中 30 例 $(75 \%)$, 習慣性扁桃炎群 が 30 例中 16 例 $(53 \%)$ ，その他の扁摘群が 7 例中 5 例 （71\%）であった.

（3）初診時主訴

初診時の主訴としては扁桃炎を繰り返すが 26 例, いび きが大きいが 24 例, 睡眠時無呼吸が 20 例であった．検 診, 他院にて扁桃肥大を指摘されたが 8 例, 食事が遅い, 大きいものが飲み込みにくいといった嚥下に関するもの が 4 例, 腎疾患のため手術を希望されたものが 2 例であっ た (表 1)。

(4) ASO

ASO 值は術前に測定した 71 例につき検討した. 陽性例 は習慣性扁桃炎群がもっとも多く10例認めたが疾患別に

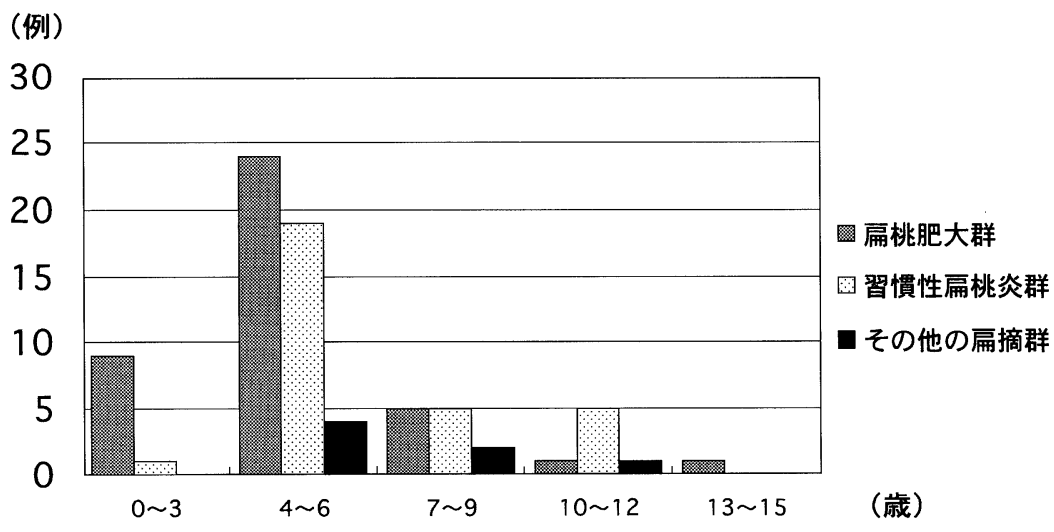

図 3 疾患別年齢分布 
(例)

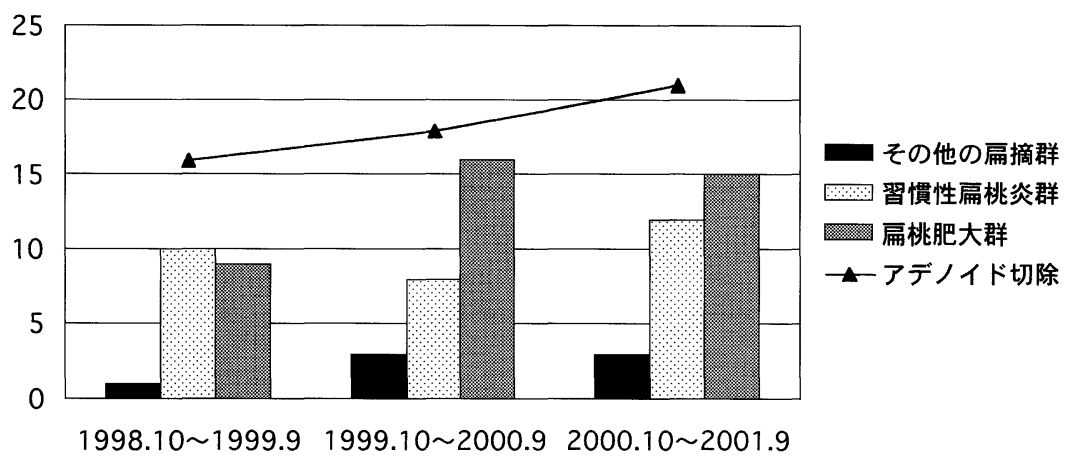

図 4 手術患者数の推移

表 1 初診時主訴

\begin{tabular}{lc}
\hline \hline & 例 \\
\hline 扁桃炎を繰り返す & 26 \\
いびきが大きい & 24 \\
睡眠時無呼吸 & 20 \\
扁桃肥大を指摘された & 8 \\
嚥下障害 & 4 \\
腎疾患がある & 2 \\
その他 & 6 \\
\hline \multicolumn{1}{c}{ 計 }
\end{tabular}

差はみられなかった（表 2)。

(5) 術式

手術は全例全身麻酔下にて施行した. 扁摘のみ行った のは 21 例で全体の $27.3 \%$ あった。併施にてアデノイ ドも切除したのは 55 例で $71.4 \%$ であった. 渗出性中耳 炎のため鼓膜チューブ留置術を行ったのは 4 例, 鼓膜切 開を行ったのは 4 例であり，これら 8 例中 7 例が同時に アデノイドを切除していた（表 3 ).

\section{（6）術後の状態}

アンケート調查の回収率は 77 例中 42 例の $54.5 \%$ で あった。疾患別にみると扁桃肥大群が 22 例, 習慣性扁桃 炎群が 17 例, その他の扁摘群が 3 例であった。

1. 改善度（図 5)

術前にみられた症状の改善度について術前の症状が全 くなくなったものを改善, 症状は残っているがかなり軽 快しているものをやや改善, 手術前と変わらなかったも のを不変, 覀くなったものを悪化, わからないの 5 段階 で回答してもらった。全体では改善 27 例 (64.3\%), や
表 2 ASO

\begin{tabular}{ccc}
\hline \hline & $<200$ (陰性) & $\geqq 200$ (陽性) \\
\hline 扁桃肥大群 & 32 & 5 \\
習慣性扁桃炎群 & 19 & 10 \\
その他の扁摘群 & 4 & 1 \\
\hline 計 & 55 & 16
\end{tabular}

表 3 術式

\begin{tabular}{lc}
\hline \hline & 症例数 \\
\hline 扁摘 & 21 \\
扁摘+チューブ & 1 \\
扁摘+アデノイド & 45 \\
扁摘+アデノイド+チューブ & 3 \\
扁摘+アデノイド+鼓切 & 4 \\
扁摘+アデノイド十その他 & 3 \\
\hline \multicolumn{2}{c}{ 計 }
\end{tabular}

扁摘：口蓋扁桃摘出術 アデノイド：アデノイド切除術 チューブ：鼓膜チューブ留置術 鼓切：鼓膜切開術

や改善 14 例 $(33.3 \%)$, 不変 1 例 $(2.4 \%)$ であった。 疾 患別にみると扁桃肥大群は改善 13 例 (59.1\%), やや改 善 9 例 (40.9\%), 習慣性扁桃炎群は改善 13 例 (76.5\%), やや改善 4 例 (23. 5\%), その他の扁摘群は改善 1 例 (33. 3 $\%)$, やや改善 1 例 (33.3\%), わからない 1 例 (33.3\%) であった。改善・やや改善を含めるとその他の扁摘群以 外は $100 \%$ でり, 高い改善率であった. アデノイドを 同時切除している症例としていない症例で改善度に差は みられなかった。

2. 満足度 (図 6) 


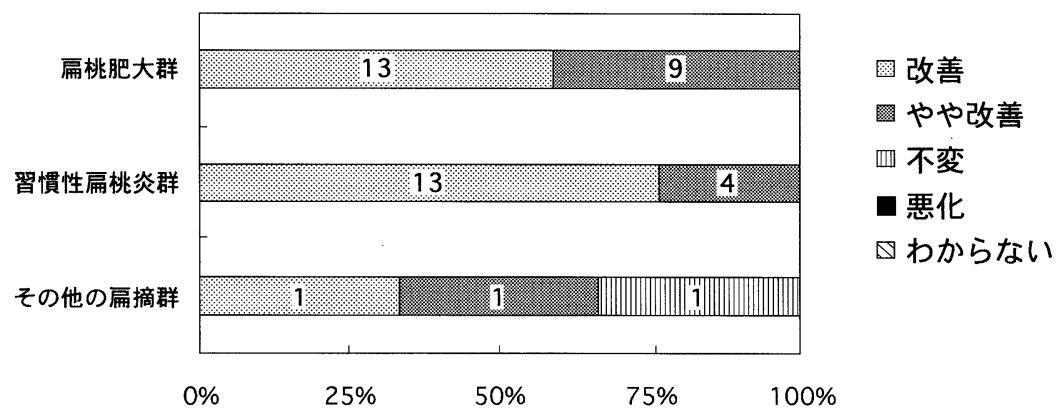

図 5 改善度

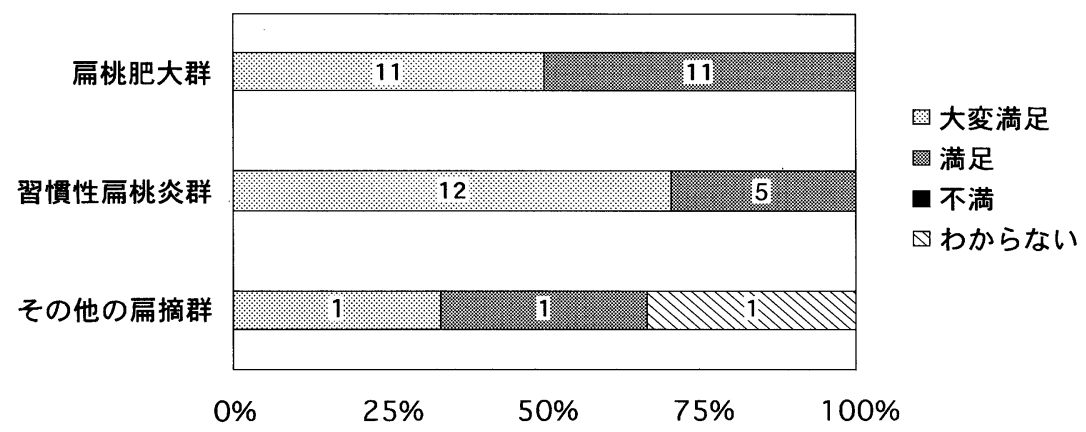

図 6 満足度

満足度は大変満足, 満足, 不満, わからないの 4 段階 で回答してもらった. 全体では大変満足 24 例 (57.1\%), 満足 17 例 (40.5\%)，わからない 1 例 (2.4\%) であっ た. 疾患別にみると扁桃肥大群は大変満足 11 例 $(50 \%)$, 满足 11 例 (50\%), 習慣性扁桃炎群は大変満足 12 例 (70.6 $\%)$, 満足 5 例 $(29.4 \%)$, その他の扁摘群は大変満足 1 例 $(33.3 \%)$, 満足 1 例 $(33.3 \%)$, わからない 1 例 $(33.3$ \%) であった. 改善度と同様で大変満足・満足を含める とその他の扁摘群を除き $100 \%$ と高い満足度が得られる 結果となった. 改善度と同様, アデノイドの切除の有無 で満足度に差はみられなかった。

\section{考察}

当科における 3 年間の統計では 10 歳以下が多く $4 \sim 6$ 歳にピークがあり，石川ら ${ }^{1)}$, 松田ら ${ }^{2)}$, 小林ら ${ }^{3)}$ の報告 と同様であった。疾患別にみると炎症のない扁桃肥大群 は 4 6 歳を中心に低年齢層に, 炎症のある習慣性扁桃 炎群・慢性扁桃炎群は肥大群に比べやや高年齢層にあっ た. 扁摘の手術件数は 3 年間では横ばいであるが, 最初 の 1 年に比し後の 2 年は扁桃肥大の割合が増えている.
また，アデノイドを同時切除する症例も年々増加してい た。これは, 近年睡眠時無呼吸症候群という病態が確立 され，その原因である扁桃肥大，アデノイド増殖症が再 び注目されており, 手術適応と考えられる症例が増えた ものと考える. また, 日常診療のなかで疾患概念の浸透 が医療サイドだけでなく患者サイドにも浸透し，いびき・ 無呼吸を主訴に来院されることが多くなった印象を受け ている，扁桃肥大のために呼吸障害や嚥下障害をきたし ている症例は，手術をすることにより発育に大きく影響 すると報告されている415). 当科にても扁桃肥大に加え肥 大による機能障害をきたしている症例は積極的に手術適 応としている，そのため年数ごとに扁桃肥大の割合が増 加したものと考える.

扁摘は耳鼻咽喉科医にとって一般的な手術であるが, 日常診療のなかで扁摘後の状態について知る機会は少な い. 術後の状態を知る目的で今回当院で行った扁摘症例 にアンケート調查を行った. 術後の改善度は習慣性扁桃 炎群に比べ扁桃肥大群の方がやや改善とする割合が高 かった．詳細をみると肥大群ではいびきの残存のためや や改善とする症例が多かった。文献的には，いびきのあ 
る症例は術後早期の症例の方が改善率が高いとする報告 もあるが ${ }^{6)}$, 今回検討してみると, 術後 1 年目のものと 術後 3 年目のもので差はみられなかった. その他の扁摘 群でわからないと回答した症例は術後 2 カ月しか経過し ていなかったため, わからないとコメントしていた．今 後の経過観察が必要と考える. その他の扁摘群を除き, 改善・やや改善を合わせると $100 \%$ の高い改善率が得ら れた。

満足度もその他の扁摘群を除き, 満足・やや満足を合 わせると $100 \%$ の高い満足度が得られた. その理由とし て挙げられたものは「熱が出なくなり, 学校を休まなく なった」「よく食べるようになり子供も自信がついたよう だ」などが多く挙げられていた。

アンケート調査による扁桃摘出術の治療効果について は，これまでにも諸家12)4) 10) の報告があり，良好な結 果が得られている. 今回われわれの検討でもその他の扁 摘群を除くと, 改善度・満足度ともに $100 \%$ といら高い 結果が得られた。

小林ら ${ }^{3)}$ は扁摘の術式の安全性について手術時間, 術 中の出血量を検討している. 当科での扁摘も小林らと同 様の術式で行っている.今回の 77 例では 3 名の術者にて 行っているが, 手術時間は $10 \sim 82$ 分で平均 39.1 分, 出 血量は $3 \sim 140 \mathrm{ml}$ で平均 $25.8 \mathrm{ml}$ であり, 小林らの報告 による経験年数 3 年目以上のものに相当した. 術後合併 症としての術後出血は 1 例もなく, やはり安全な術式と 考えられた。 また，このことにより入院期間が延長する こともなく患者の満足につながったと考えられた。

\section{結 語}

1） 1998 年 10 月から 2001 年 9 月までの 3 年間で行っ た扁摘症例 77 例について検討した。

2）男性 52 例, 女性 25 例と男性に多く, $4 \sim 6$ 歳に ピークを認めた.

3）疾患別では扁桃肥大群が多く,アデノイド切除例が 年数ごとに増加していた。

4）初診時主訴は扁桃炎を繰り返す，いびき，睡眠時無 呼吸が多かった。
5）扁摘のみは 21 例，アデノイドを合併切除したもの は 55 例, 渗出性中耳炎の手術を併施したものは 8 例で あった。

6）アンケート調査ではその他の扁摘群を除き，改善 度・満足度ともに高い結果であった。

本論文の要旨は第 27 回中・四国地方部会において発表した。

\section{参考文献}

1）石川忠孝, 原㴊保明, 形浦昭克：当科における過去 10 年間 の扁桃摘出術の検討一習慣性扁桃炎を中心に一. 耳鼻臨床 補 $84: 70 \sim 76,1995$.

2）松田史明, 三部重雄, 原㴊保明, 他: 当科における 10 年間 の扁摘の統計学的観察. 耳喉 $57: 589 \sim 595,1985$.

3）小林隆一, 唐木將行, 武田純治, 他: 当科における口蓋扁 桃摘出術の検討. 口咽科 $11: 425 \sim 431,1999$.

4）石塚洋一, 秋元淑子, 鰐㴊信子, 他：小児のアデノイド • 口蓋扁桃の呼吸や嚥下に及ぼす影響. 小児耳 $11: 31 \sim 35$, 1990.

5）大津信也, 石田達也, 和田好純, 他 : 幼小児におけるアデ ノイド切除・口蓋扁桃摘出術施行患者の経過観察一主とし てアンケート調査から一.耳鼻臨床 補 $61: 141 \sim 145,1993$.

6) 米井 潔, 木村裕毅, 太田文彦: 口蓋扁桃摘出術の遠隔成 績一10 年間にわたる臨床統計的観察一. 日扁桃誌 $25: 49$ $\sim 55,1986$.

7）橋口一弘, 小川浩司, 山崎嘉司, 他: 当院における習慣性 扁桃炎, 単純扁桃肥大, 慢性扁桃炎の扁桃剔除術の検討. 日扁桃誌 $32: 80 \sim 84,1993$.

8）中野友明, 塩谷隼人, 長 寛正, 他 : 扁桃摘出術について. 大阪市勤務医師会研究年報 : $531 \sim 534,1995$.

9）橋本循一, 石塚洋一, 木村元俊, 他: アンケート調查より みた扁桃摘出術の効果. 耳展 $30: 661 \sim 667,1987$.

10）小島未知郎, 吉見龍一郎, 山口 隆, 他: 口蓋扁桃摘出術 とその長期経過観察. 日扁桃誌 $26: 173 \sim 179,1987$.

原稿受付：平成14年 6 月 14 日 原稿採択 : 平成14年10月 9 日 別刷請求先 : 唐木りえ 于760-0018 高松市天神前4-18 KKR高松病院耳鼻咽喉科 